\title{
Analysis of Capillary Water Migration Law of Compacted Loess in Ningxia
}

\author{
Zizhi Cui ${ }^{1 *}$, Xin Jing ${ }^{1}$, Jiaxing Hao ${ }^{2}$, ShuIng Doh ${ }^{3}$ \\ ${ }^{1}$ College of Civil and Hydraulic Engineering, Ningxia University, Yinchuan, China \\ ${ }^{2}$ China Railway 14 Bureau Group Corporation, Shandong, China \\ ${ }^{3}$ Faculty of Civil Engineering Technology, Universiti Malaysia Pahang, \\ LebuhrayaTun Razak26300, Malaysia
}

Received: 9 April 2020

Accepted: 19 May 2020

\begin{abstract}
Capillary water is the main cause of freezing damage and collapsible damage of compacted loess. Therefore, researching capillary water migration law of compacted loess is the key to solve various damage in the infrastructure construction of loess. Different regions have different climatic conditions, which make the physical and mechanical properties of the loess is different. In order to reveal the capillary water migration law of compacted loess in Ningxia, the moisture migration law of compacted loess with different degrees of compaction was studied by using standpipe method. The results show that the migration rate of capillary water is rapid at the early stage and gradually became slower with the increase of time, which is negatively related to the degree of compaction and migration height. The maximum migration height of capillary water increases exponentially with the increase of compactness. Migration rate and migration height of capillary water are related to capillary water potential, gravitational potential, and pipe-resistance of capillary. In this study, the relational equation can predict capillary water distribution and the migration height of compacted loess was newly established. This equation can also provide a reference to reduce various damage and freeze-thaw effect in compacted loess.
\end{abstract}

Keywords: capillary water, compacted loess, compactness, saturation, relational equation

\section{Introduction}

Loess is special quaternary sediment, which has characteristics of porosity, collapsibility, and high permeability [1-4]. The loess distribution in China is located between $34^{\circ}$ and $45^{\circ}$ north latitude which is estimated about $4.9 \%$ of the world's total distribution

*e-mail: czz2062428@qq.com area of loess and loess-shape rocks, with a total area of approximately 630,000 square kilometers [5-7]. Therefore, the foundation engineering construction related to loess is inevitable, and a series of problems caused by the physical and mechanical characteristics of loess need to be solved, such as foundation settlement, collapse deformation, landslide, soil erosion, and freezing damage, which spreads throughout the loess distribution region [8-10]. Ningxia Hui Autonomous Region of China is located in the northern Loess Plateau, which belongs to serious collapsible loess 
regions [11-14]. It is cold and dry in winter, large areas of farmland are irrigated before winter, which makes the frost-heave of soil large and the rate of frost-heave reaches $13.0 \%$, canals and subgrade projects are severely damaged by frost [15-17]. However, capillary moisture is the main source of water supply during the soil frost-heave process, which is an important factor affecting soil frost-heave deformation [18]. In order to reduce the freezing damage, satisfy the needs of production construction and theoretical research of compacted loess, investigating the capillary moisture migration law of compacted loess is necessary.

Previous studies have shown that the migration law of capillary water is related to temperature potential, gravitational potential, and matrix potential [19]. The temperature potential refers to the effect of temperature changes caused by the external environment on the migration direction, migration height and rate of capillary water. Gravity potential means that the selfgravity of capillary water has different effects on the migration law of capillary water in different directions. Matrix potential is related to the influence of different ionic and molecular attractive force on capillary water migration in different soils, which is caused by their different mineral components and physical and mechanical properties. Freeze-thaw cycles (FT) and dry-wet (TW) cycles are the main causes of damage to compacted loess. The freeze-thaw cycle is the main research direction of temperature potential on the migration law of capillary water, which is a seasonal process and exists widely in seasonal frozen ground regions. Meanwhile, the freeze-thaw cycle is usually accompanied by dry-wet cycle, both of which can decrease the mechanical properties of soils [20-24]. Capillary water migration rate in the compacted loess is inversely related to the number of dry-wet cycles, initial water content and compaction degree [25]. It is dry and windy in winter that capillary water migrates to ground surface due to strong evaporation. At the same time, the salt in the soil is also transported to the surface and accumulated under the action of capillary water [26]. When the temperature is lower than $0^{\circ} \mathrm{C}$, the capillary water in the soil will gradually be transformed into solid ice from top to bottom of the ground, which will attract moisture of soil migrate to the frozen zone too $[27,28]$, the soil frosts heave and the volume will increase. As temperature increases, the water molecules between the soil particles are transformed from solid ice to liquid water. Meanwhile, the moisture content of soil increases, porosity increases. Accordingly, shear strength, compression strength, cementation between soil particles, compaction, and elastic modulus of the soil would be decreased during this process, all of which would cause collapsible deformation and uneven settlement of the soil [29].

The migration law of capillary water is also affected by gravitational potential. The migration rate of capillary water is negatively correlated with the migration height
$[30,31]$. The higher the migration, the greater the gravitational potential energy of the water molecules which can decrease the migration rate of moisture. The distribution of capillary water is also related to the nature of the soil. Different mineral components and ionic content will cause differences in soil matrix suction. Capillary water migration equation and simplified equation based on particle size distribution can effectively describe the soil water retention curve and determine the soil hydraulic conductivity [32]. The study of geotechnical characteristics of loess shows that open pores in the soil are the main reason for loess collapsing [33]. Higher compaction degree and smaller water content can effectively reduce the rate of water migration and avoid the collapse of the loess [34].

Generally speaking, different soils have various physical and chemical properties [35, 36], such as compaction, saturation, moisture content, dry density, thickness of combined water film, and so on. Different matrix potential can influence migration height and rate of capillary water too. In recent years, more and more scholars pay emphasis on the improvement of loess collapsible by adding additives loess and better drainage system, which can effectively improve the collapsible damage of the compacted loess [37-40].

Soil quality is an important factor in controlling capillary water migration. However, the interaction between the external environment and the soil will affect the soil quality. Accordingly, the hydro-geographic conditions in different regions will have different effects on the physical and mechanical properties of the soil, the physical and mechanical characteristics of loess in different regions are different. Ningxia loess has smaller content of hydrophilic minerals and smaller amount of clay, so it has a different capillary water migration law from other regions. However, the research on the capillary water migration law of Ningxia compacted loess is still in its infancy. In order to understand the capillary water migration law of compacted loess in Ningxia and provide a reliable theoretical basis for basic engineering construction, in this study a capillary water distribution equation based on saturation was established, and the effect of compaction on Capillary water saturation was analyzed. This study made a foundation of Ningxia compacted unsaturated loess in freeze-thaw cycles, and it provides a significant method for the evaluation and prevention of freezing damages in engineering.

\section{Materials and Methods}

\section{Experimental Materials}

According to the Specification of Soil Test (SL2371999), the loess used in the test was taken from Tongxin County of Ningxia Hui Autonomous Region, the physical and mechanical indexes of the loess are shown 
Table 1. Basic physical and mechanical properties of loess.

\begin{tabular}{|c|c|}
\hline Properties & Numerical value \\
\hline Density $\rho\left(\mathrm{g} / \mathrm{cm}^{3}\right)$ & 1.56 \\
\hline Water content $w(\%)$ & 12.2 \\
\hline Specific gravity of solid particles $\mathrm{G}_{\mathrm{s}}$ & 2.72 \\
\hline Optimal water content $w_{\text {opt }}(\%)$ & 16.0 \\
\hline Maximum dry density $\rho_{\text {dmax }}\left(\mathrm{g} / \mathrm{cm}^{3}\right)$ & 1.72 \\
\hline Liquid limit $\mathrm{w}_{\mathrm{L}}(\%)$ & 27.2 \\
\hline Plastic limit $\mathrm{w}_{\mathrm{p}}(\%)$ & 15.0 \\
\hline
\end{tabular}

in Table 1. XRD analysis showed that the main minerals were quartz, calcite, $\mathrm{Na}_{2} \mathrm{Al}_{2} \mathrm{Si}_{5} \mathrm{O}_{14}$, and mica, as shown in Fig. 1. The particle size distribution is shown in Fig. 2. It is mainly silt-grained soil of $0.005 \mathrm{~mm} \sim 0.075$ $\mathrm{mm}$, accounting for $81.3 \%$, and the clay-grained content is small, about $13.9 \%$. The SEM micro-morphology of the loess particles is shown in Fig. 3. The morphology of loess particles is mainly granular, angular, elliptical, and surface is slightly convex. The surface of the coarse powder particles is adhered by small sticky particles or colloidal particles. There are few cohesive particles with a particle size smaller than $5 \mathrm{um}$.

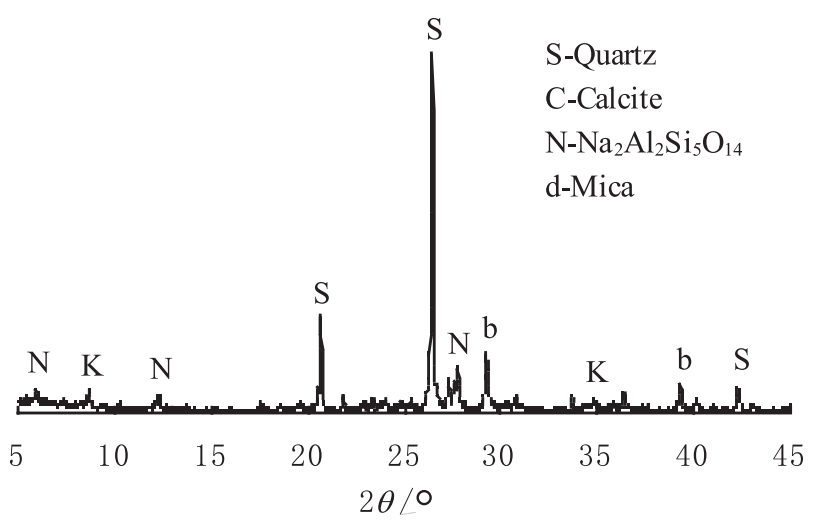

Fig. 1. XRD analysis of loess.

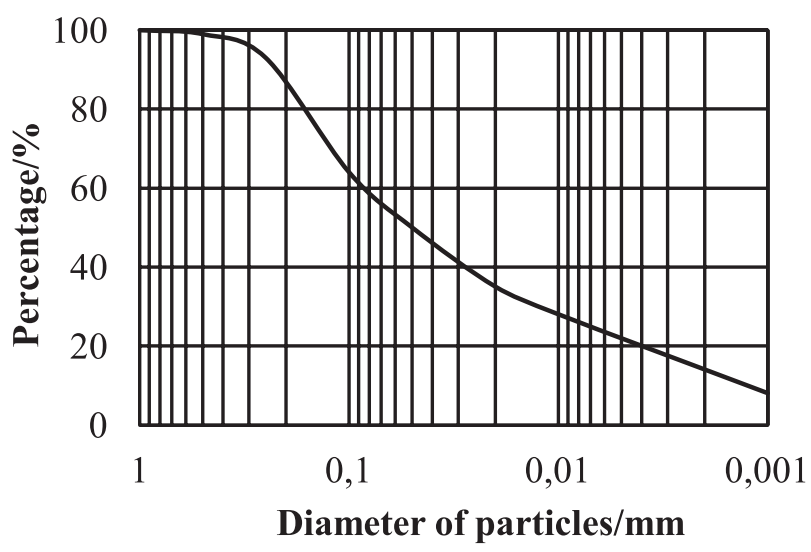

Fig. 2. Particle size analysis of loess.

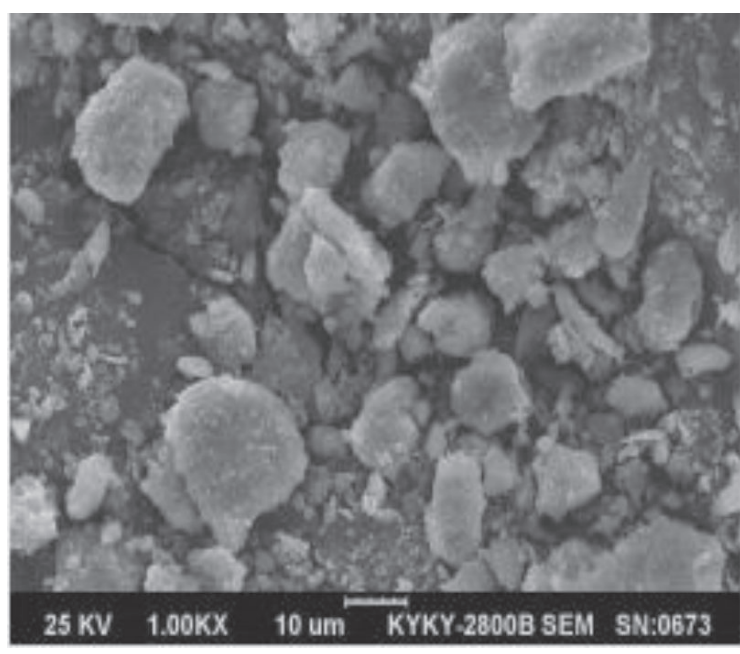

Fig. 3. The scanning electron microscope (SEM) of loess particle morphology.

\section{Experimental Methods}

\section{Experimental Scheme}

The physical and mechanical indexes of samples are shown in Table 2. the compaction degree was set at four levels of $0.86,0.90,0.94$, and 0.98 . At temperature of $20 \pm 1^{\circ} \mathrm{C}$, studied the capillary moisture migration height of loess with different compaction degrees. The capillary moisture migration rate is fast in the early period and slower in the later period, so the observation interval is set relatively short in the early days and long when it is stable or near the top of the tube. the early data observation interval was $1 \mathrm{~d}, 3 \mathrm{~d}, 7 \mathrm{~d}, 12 \mathrm{~d}$ respectively. when capillary action is stable or near the top of the tube, further data are observed at every $12 \mathrm{~d}$ until $72 \mathrm{~d}$. In order to facilitate the preparation of samples and observe the position of the vertex about capillary moisture, the water content used in the sample preparation was $w_{0}=8.0 \%$.

\section{Preparation of Samples}

The loess was air-dried and crushed, and water was added according to the moisture content set in the plan. It was then mixed evenly and put in a sealed bag, and placed in a moisturizing container for not less than 24 hours to fully mixed the soil particles and water. According to the designed compaction and the thickness of each layer $(5 \mathrm{~cm})$, the quality of wet soil in each layer was calculated, and compacted each layer in an organic-glass sample tube. The sample is $10 \mathrm{~cm}$ in diameter and $200 \mathrm{~cm}$ in height.

\section{Capillary Water Migration Test}

The migration height of capillary moisture was measured by the standpipe method. The test device is shown in Fig. 4. The inner diameter of the standpipe 
Table 2. Physical properties of Samples.

\begin{tabular}{|c|c|c|c|c|}
\hline Sample number & Degree of compaction $\lambda_{c}$ & Dry density $\rho_{d}\left(\mathrm{~g} / \mathrm{cm}^{3}\right)$ & Porosity ratio $e$ & Water content $w_{o}(\%)$ \\
\hline 1 & 0.86 & 1.48 & 0.84 & 8.0 \\
\hline 2 & 0.90 & 1.55 & 0.76 & 8.0 \\
\hline 3 & 0.94 & 1.62 & 0.68 & 8.0 \\
\hline 4 & 0.98 & 1.69 & 0.61 & 8.0 \\
\hline
\end{tabular}

was $10 \mathrm{~cm}$ and the height was $200 \mathrm{~cm}$. A ruler was attached upward from $10 \mathrm{~cm}$ at the bottom of the standpipe to locate the position of the vertex about capillary moisture. A $10 \mathrm{~mm}$ hole was drilled every $10 \mathrm{~cm}$ from $15 \mathrm{~cm}$ up from the bottom to determine the moisture content of the soil. The top of the standpipe was wrapped with a plastic film with small holes to prevent the water in the soil sample at the top of the pipe from evaporating too quickly. A 400-mesh gauze pad was placed on the bottom to prevent soil from escaping into the water. The bottom of the water storage tank was covered with fine-stones of $5 \mathrm{~cm}$, and an overflow hole was opened at $15 \mathrm{~cm}$. The thin stream continuously replenishes water, and the depth of the vertical pipe in the water was always maintained at $10 \mathrm{~cm}$. The migration height of capillary water was observed by the direct-observation method under the guidance of technical code (SL237-1999), according to the color change of the soil sample and the ruler attached to the vertical pipe.

The moisture content sensor can continuously monitor the dynamic changes of soil moisture, but there are many factors that affect the accuracy of the measurement, and there are certain measurement errors [41-45]. Especially for saline soils, the measurement results are significantly diverse due to different salt content. Although the quality-method cannot continuously monitor the soil moisture content, it has few influencing factors and high measurement accuracy.

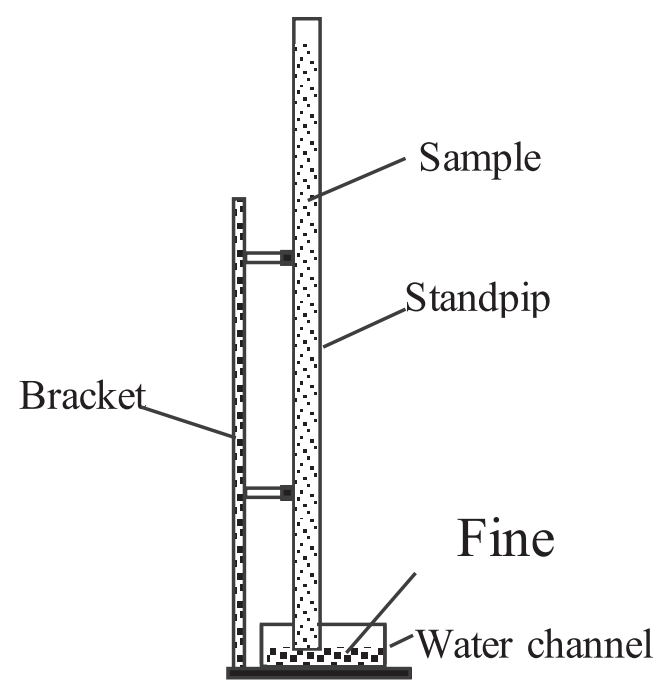

Fig. 4. The device of capillary water migration test.
The content of soluble salt in loess is more than others, and it is unevenly distributed due to migration of capillary moisture [46-48]. In the study of soil freeze-thaw effect, the most concerned is the steadystate moisture content when capillary moisture migrations to reach stability, so the quality-method was used to determine the moisture content. After the capillary moisture migration height was stable, samples were taken at about $2 \mathrm{~cm}$ and $5 \mathrm{~cm}$ from the tube wall, and the average value was used as the measurement result.

\section{Results and Discussion}

\section{Analysis of Water Migration}

The relationship between the capillary moisture migration height $h$ and time $t$ of loess samples with different compaction degrees is shown in Fig. 5, and the moisture migration rate $v$ of the corresponding period is shown in Fig. 6.

It can be seen from Fig. 5 and Fig. 6 that the early migration of capillary moisture in the compacted loess was fast, especially on the first day, the sample with a compaction degree of 0.86 had a capillary moisture migration rate of $60 \mathrm{~cm} /$ day. With the increase of time, the migration rate of capillary moisture decreased rapidly. The migration rate at the $2 \sim 3 \mathrm{~d}$ was only $1 / 2.5 \sim 1 / 4.7$ of the migration rate at the $1 \mathrm{~d}$, which had dropped by $60 \% \sim 78 \%$. After $36 \mathrm{~d}$, the rate of capillary moisture migration was less than $1.0 \mathrm{~cm} /$ day. The

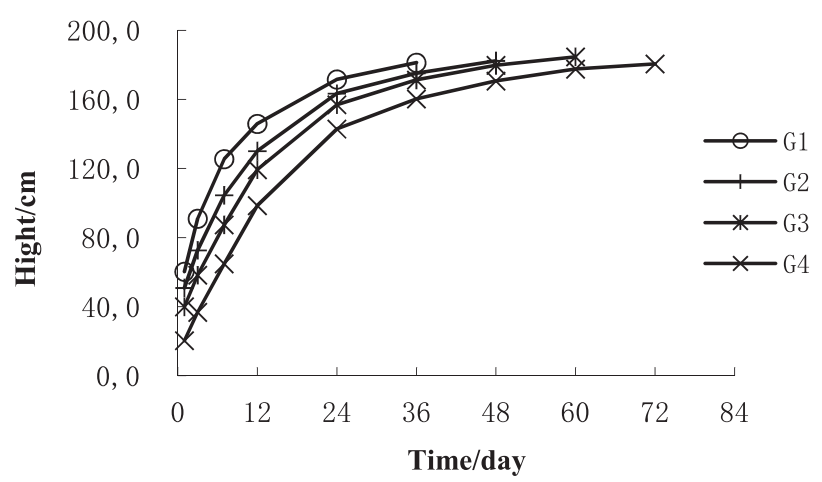

Fig. 5. Relationship between capillary moisture migration height and time. 


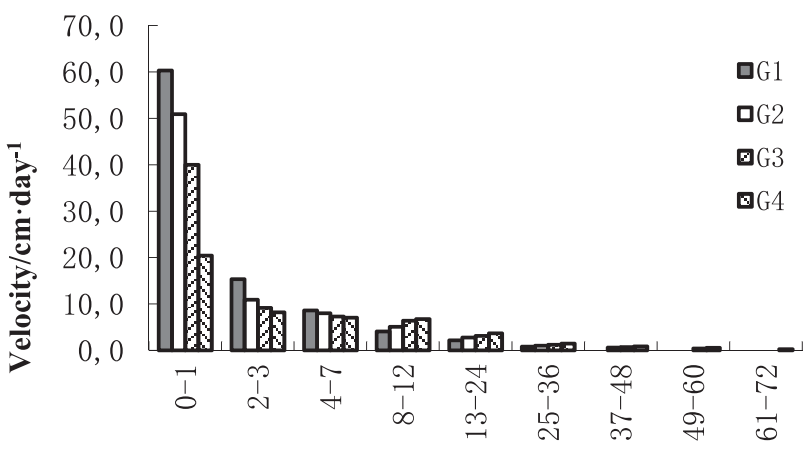

Time/day

Fig. 6. Relationship between capillary moisture migration rate and time.

effect of compaction on the migration rate of capillary moisture was particularly obvious in the early stage, but it was weak in the later stage. The rate on the first day was $40 \mathrm{~cm} /$ day, it was less than $0.3 \mathrm{~cm} /$ day after $36 \mathrm{~d}$. Capillary moisture migration rate decreased with the increase of compaction before $7 \mathrm{~d}$, and then increased with the increase of compaction. The capillary moisture migration height increased with time, and stabilized after a certain period which was related to the degree of compaction. The higher the degree of compaction, the longer the time for the capillary moisture migration height to reach stability.

Capillary moisture potential, gravity potential, and resistance of capillary wall were the decisive factors at capillary moisture migration rate [49]. The potential energy of capillary moisture was related to capillary diameter, soil particle thickness, material composition, and water properties. For example, if the capillary diameter was small, the soil particles were fine, the constituents were highly hydrophilic, the degree of water mineralization and cations were small, the capillary moisture potential would be greater than other conditions. The resistance of capillary wall was related to capillary diameter and morphology, the property and thickness of water bound to the tube wall, the shape and surface state of soil particles, and the rate of capillary moisture migration $[50,51]$. If the capillary diameter was small, the longitudinal bend or planar shape was flat, the water binding on the wall of pipe was strongly bound-moisture, the combined water film was thick, the soil particles were angular, the surface was rough, the resistance of pipe-wall would greater than other conditions.

Capillary moisture was driven by the surface tension of water vapor, overcomes gravity and the resistance of capillary wall to move upward. Early in the test, capillary moisture had a small migration height, low gravity potential, relatively thin water film combined with the tube wall, small resistance to the tube wall, and high capillary moisture migration rate. As the capillary moisture migrations, the gravity potential increases. At the same time, the tube wall in the capillary moisture infiltration area became thicker with the water film, the resistance of the pipe wall increased, and the capillary moisture migration rate decreased rapidly. Higher compactness of loess results in a reduction of the capillary while increasing the capillary moisture potential and the pipe wall resistance. when compaction degree is greater than 0.86 , the capillary wall resistance of the loess increases faster than the capillary moisture potential with the increase of the compaction degree, the capillary moisture migration rate decreases, and the time to reach the maximum height was increased.

Fig. 5 shows that the capillary moisture migration height $h$ and time $t$ of each sample show a clear hyperbolic relationship.

$$
h=\frac{t}{a+t} h_{u}
$$

In the Equation 1: $a$ and $h_{u}$ are the fitting coefficients to be determined, $h_{u}$ is the extreme value of $h$ when $t$ tends to infinity, that is, the maximum height of capillary moisture, $\mathrm{cm}$.

The fitting coefficients $a$ and $h_{u}$ and the correlation coefficient $R^{2}$ of the capillary moisture migration equation of each sample are shown in Table $3, R^{2}$ in Table 3 are all close to 1.0, and the relationship between capillary moisture migration height and time is fitted with a hyperbolic relationship, which has a high correlation of fit.

Using the least squares method to further fit the relationship among $a, h_{\mathrm{u}}$, compaction degree $\lambda_{c}$ and porosity $e$ (Fig. 7), which can get:

$$
\begin{gathered}
h_{u}=216.33 \lambda_{c} c^{0.7099}=184.55 e^{-0.2984} \\
a=15.0 \lambda_{c}{ }^{10.212}=1.532 e^{-4.2791}
\end{gathered}
$$

The correlation coefficient $R^{2}$ of fitting coefficient $a$ and $h$ has an obvious correlation with compaction degree $\lambda_{c}$ and porosity $e$, which are all close to 1 . From Equation 2 and Equation 3, it can be seen that the maximum migration height of capillary moisture increases exponentially with the degree of compaction, decreases with the exponential decreasing power ratio of porosity, and It is consistent with the Hazen formula $h_{c}=\mathrm{Ce}^{-1}$ for estimating the maximum migration height of sandy capillary moisture [52]. When the radius of the pores between the particles is less than $2.75 \mu \mathrm{m}$, the capillary moisture phenomenon does not occur, and the corresponding particle size is $0.0024 \mathrm{~mm}$ [53]. The grain composition of Ningxia loess is mainly powder and less than $4 \%$ of particles smaller than $0.002 \mathrm{~mm}$. The mineral composition is mainly quartz, calcite and mica with small hydrophilicity, the combined water film is thin, even in the most compact state, there are few pores with a radius less than $2.75 \mu \mathrm{m}$, and the path of capillary moisture migration will not be blocked. Similar to silt or coarse-grained soil, the maximum 
Table 3. The fitting parameter capillary migration model.

\begin{tabular}{|c|c|c|c|}
\hline Sample number & Fitting coefficient $a$ & Maximum height of capillary moisture $h_{u}(\mathrm{~cm})$ & Correlation coefficient $R^{2}$ \\
\hline 1 & 3.332 & 195.8 & 0.99 \\
\hline 2 & 5.060 & 199.2 & 0.99 \\
\hline 3 & 7.259 & 205.5 & 0.99 \\
\hline 4 & 13.041 & 214.9 & 0.99 \\
\hline
\end{tabular}
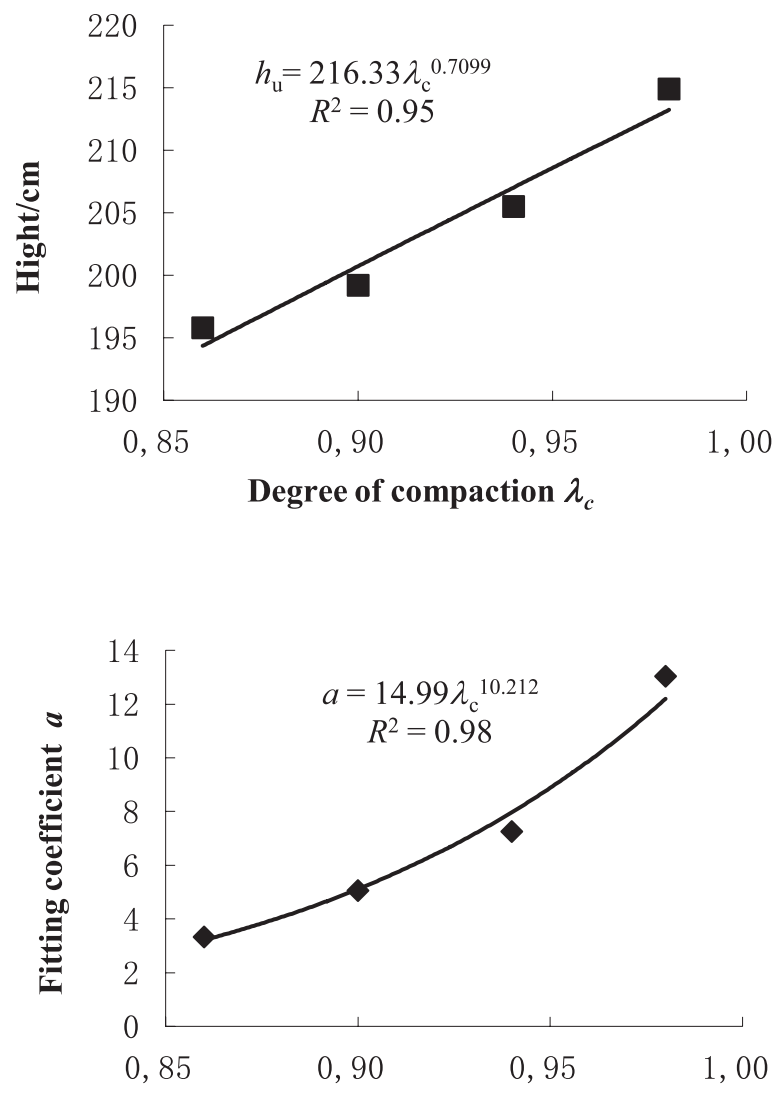

Degree of compaction $\lambda_{c}$

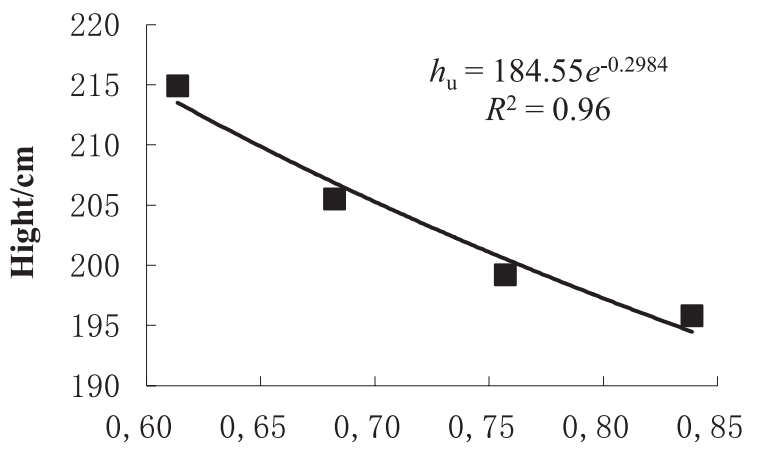

Porosity ratio $e$

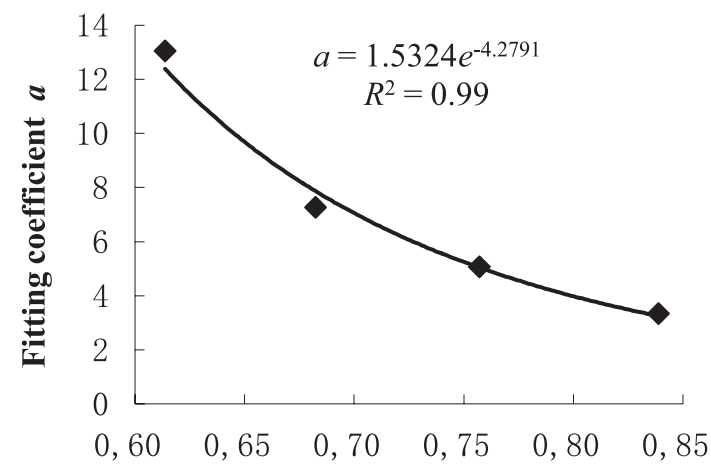

Porosity ratio $e$

Fig. 7. Fitting analysis of regression parameters.

Table 4. Prediction and verification of capillary moisture migration height.

\begin{tabular}{|c|c|c|c|c|}
\hline Samples number & Measured value $(\mathrm{cm})$ & Predicted value $(\mathrm{cm})$ & Residuals $(\mathrm{cm})$ & Relative residuals $(\%)$ \\
\hline 1 & 178.4 & 175.0 & 3.4 & 1.9 \\
\hline 2 & 169.8 & 168.7 & 1.1 & 0.6 \\
\hline 3 & 161.6 & 163.2 & -1.6 & -1.0 \\
\hline 4 & 146.4 & 146.6 & -0.2 & -0.1 \\
\hline
\end{tabular}

migration in capillary moisture increases with the degree of compaction. The maximum migration height of capillary moisture in compacted loess depends mainly on the potential energy of capillary moisture and has nothing to do with capillary wall resistance.
In the equation $h_{u}=184.55 e^{-0.2984}$, the absolute value of the index of the void ratio $e$ is 0.2984 , which is far smaller than the absolute value of the index of $e=1.0$ in the Hazen formula. It is difficult to choose a suitable value of $c$, and the Hazen equation is used to accurately 


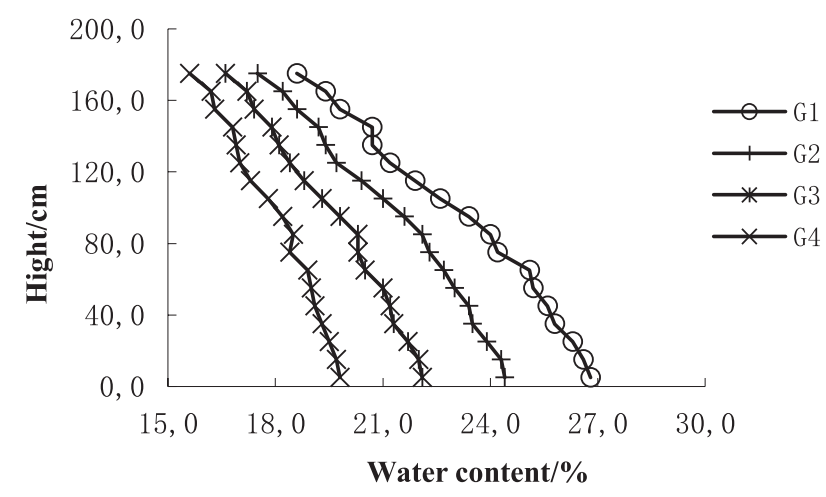

Fig. 8. Distribution of water content with height.

predict the maximum height of capillary moisture in Ningxia loess. The maximum migration of capillary moisture in compacted loess is affected by porosity, but it is far less sensitive than in sand.

In order to verify the reliability of the equation, the capillary moisture migration height of each group of samples was measured during the test. The measured values of the capillary moisture migration height of each group of samples for $28 \mathrm{~d}$, the equation predicted values, and the residuals and relative residuals of the measured and predicted values are listed in Table 5. It can be seen from Table 4 that the relative residuals between the predicted value and the measured value of the capillary moisture migration height equation are within $5 \%$, and the equation prediction results are accurate and reliable.

\section{Analysis of Capillary Moisture Distribution}

Fig. 8 shows the steady-state moisture content distribution of the loess samples with different degrees of compaction, and Fig. 8 is the saturation distribution. It is observed from Fig. 8 and Fig. 9 that the moisture content of each test point of the sample is significantly larger than the initial moisture content of the sample,

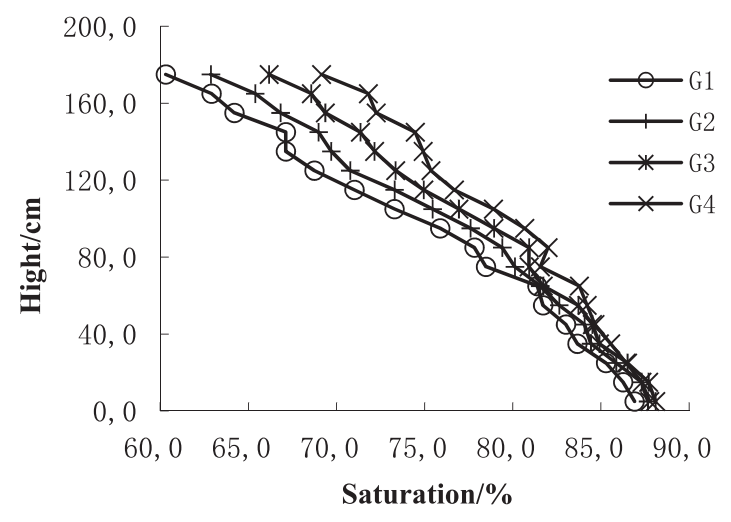

Fig. 9. Distribution of saturation with height.

this phenomenon indicated that moisture of the four samples had migration to the top of the standpipe. The water content and saturation decreased with the increase of height. Within the range of $65 \mathrm{~cm}$ from the water level, the water content and saturation changed slowly along with migration height, and the saturation can reach more than $80 \%$, the other part above $65 \mathrm{~cm}$ decreased slightly with the increase of height. The moisture content of the sample at the same height decreased obviously with the increase of the compaction degree. The saturation increased with the increase of the compaction degree, but the change of saturation was not obvious with the increase of compaction in the regions with high saturation.

From Table 5, Table 6, Table 7 and Table 8, regression analysis and optimization were applied to obtain the distribution equations of moisture content and saturation along with the height of loess with different compaction degrees.

$$
\begin{gathered}
w=63.8-0.0370 h-43.3472 \lambda_{c} \\
S_{r}=89.9-0.1370 h
\end{gathered}
$$

Table 5. Variance analysis results of water content.

\begin{tabular}{|c|c|c|c|c|c|}
\hline & Degree of freedom & Error sum of squares & Mean square deviation & $\mathrm{F}$ & Significance F \\
\hline $\begin{array}{c}\text { Regression } \\
\text { analysis }\end{array}$ & 1 & 909.883 & 909.883 & 1031.009 & $5.8807 \mathrm{E}-16$ \\
\hline Residual error & 16 & 14.1203 & 0.8825 & & \\
\hline Total & 17 & 924.0033 & & & \\
\hline
\end{tabular}

Note: because the correlation between saturation and compaction is very low, the average value of the four samples is taken as the result for regression analysis, the degree of freedom is 17.

Table 6. Regression parameters of water content.

\begin{tabular}{|c|c|c|c|c|c|c|}
\hline & Coefficients & Standard error & $\mathrm{t}$ Stat & P-value & Lower 95\% & Upper 95\% \\
\hline Intercept & 89.9326 & 0.4434 & 202.8422 & $1.024 \mathrm{E}-28$ & 88.9927 & 90.8725 \\
\hline Hight & -0.1370 & 0.0043 & -32.1093 & $5.881 \mathrm{E}-16$ & -0.1461 & -0.1280 \\
\hline
\end{tabular}


Table 7. Variance analysis results of saturation.

\begin{tabular}{|c|c|c|c|c|c|}
\hline & Degree of freedom & Error sum of squares & Mean square deviation & F & Significance F \\
\hline Regression analysis & 2 & 536.3223 & 268.161 & 841.911 & $3.399 \mathrm{E}-49$ \\
\hline Residual error & 69 & 21.9775 & 0.3185 & & \\
\hline Total & 71 & 558.2999 & & & \\
\hline
\end{tabular}

Table 8. Regression parameters of saturation.

\begin{tabular}{|c|c|c|c|c|c|c|}
\hline & Coefficients & Standard error & $t$ Stat & P-value & Lower 95\% & Upper 95\% \\
\hline Intercept & 63.786 & 1.375 & 46.399 & $9.254 \mathrm{E}-54$ & 61.043 & 66.528 \\
\hline Hight & -0.037 & 0.001 & -28.885 & $2.892 \mathrm{E}-40$ & -0.039 & -0.034 \\
\hline Degree of compaction $\lambda_{\mathrm{c}}$ & -43.347 & 1.487 & -29.146 & $1.628 \mathrm{E}-40$ & -46.314 & -40.380 \\
\hline
\end{tabular}

The significance parameter $F$ of the water content relationship equation is 841.911, the correlation coefficient $R^{2}$ is 0.96 , and the critical value $F_{0.99}=4.79$. The $F$ of the saturation relationship equation is 1031.0, the correlation coefficient is 0.98 , and the critical value is $F_{0.99}=8.53$. It can be concluded from the above numerical analysis. Both of the water content relationship equation and the saturation relationship equation were highly significant and have a good correlation with factors. The saturation distribution equation has nothing to do with compaction, which indicated that the effect of compaction on saturation is not obvious.

The steady-state water content distribution curve of soil in the capillary moisture migration area is also the soil-water characteristic curve [54, 55]. Equation 4 and Equation 5 are soil-water characteristic curves characterized respectively by mass water content and saturation. The soil-water characteristic curve characterized by saturation which had nothing to do with compaction. „In a wide range of matric suction, saturation is not affected by porosity" [56-58], which can be mutually proved by Equation 5 .

In order to compare and analyze the degree of influence of compaction on water content and saturation, analysis of variance was performed respectively on

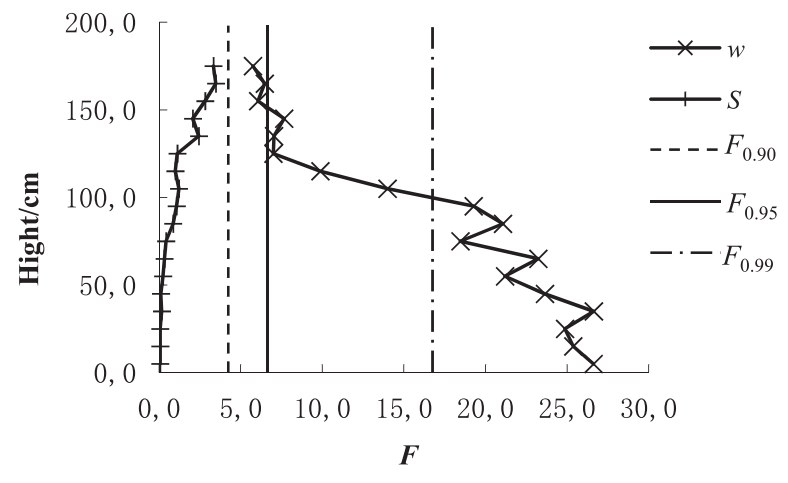

Fig. 10. Distribution of $F$ with height. water content and saturation. The distribution of significance parameter $F$ along the height is shown in Fig. 10.

Fig. 10 revealed that the $F$ of the saturation was much smaller than the $F$ of the water content in the range of moisture migration height, which indicated that the impact of the compaction on the saturation was less obvious than the effect of the water content. The $F$ about water content was all greater than $F_{0.90}$, and gradually increased from top to bottom. The effect of compaction on water content had increased rapidly from obvious to very obvious and then reach to the most obvious. The part of obvious and very obvious account for a large proportion, was about $85 \%$. The $F$ about saturation were all less than $F_{0.90}$, and the impact of compaction on saturation was not obvious, mainly because saturation was a combination of water content and porosity. According to the variance theory, if the influence of a factor was not obvious, it can be seen that the factor has no effect. Therefore, when the degree of compaction of the loess is greater than 0.86 , the effect of the compaction degree on the soil saturation in the capillary moisture migration area can be ignored. It can be inferred that loess has a limited increase or decrease in density after the compaction due to changes in load, temperature, humidity, and other factors, the steady-state water content in the capillary moisture migration zone increases and decreases, while the saturation remains unchanged. This inference provides a theoretical basis for the study of the effects of freezethaw cycles of unsaturated compacted loess on the hydration cycle.

\section{Conclusions}

This paper presents a study under the condition that the compaction degree is not less than 0.86 , with a powder content of about $80.0 \%$ and the main mineral composition is mainly composed of Quartz, Calcite, $\mathrm{Na}_{2} \mathrm{Al}_{2} \mathrm{Si}_{5} \mathrm{O}_{14}$ and Mica. The migration of capillary 
moisture in Ningxia compacted loess is studied by using the standpipe method, and the following conclusions are drawn:

(1) The capillary moisture migration height of Ningxia compacted loess is larger than $200 \mathrm{~cm}$. The maximum migration height increases exponentially with the increase of compactness.

(2) The effect of compactness on saturation is not obvious. Accordingly, it can be assumed that the saturation of the loess is almost unchanged after freezethaw cycles, when studying the effects of freeze-thaw cycles on capillary water migration laws of loess.

(3) The moisture content decreases with the increase of height, and the moisture content decrease rate increases with the increase of height. The moisture content of the sample at the same height decreases as the degree of compaction increases.

(4) The newly established equations can effectively reflect the relationship between saturation, compaction and capillary moisture migration height, and provide a theoretical basis for the study of freeze-thaw deformation of loess engineering.

\section{Acknowledgements}

The project is supported by Scientific research project of higher education in Ningxia (NGY2018027).

\section{Conflict of Interest}

The authors declare no conflict of interest.

\section{References}

1. YUAN Z., WANG L. Collapsibility and Seismic Settlement of Loess. Engineering Geology, 105 (1-2), 119, 2009.

2. ZHAO G., REN K., MA Q. Research on Collapse Failure Process and Mechanism of Earthen Sites under the Action of Capillary Water. Applied Mechanics and Materials.; Trans Tech Publ, 438, 1226, 2013.

3. KANKANAMGE L., JOTISANKASA A., HUNSACHAINAN N., KULATHILAKA A. Unsaturated Shear Strength of a Sri Lankan Residual Soil from a Landslide-Prone Slope and Its Relationship with Soil-Water Retention Curve. International Journal of Geosynthetics and Ground Engineering, 4 (3), 20, 2018.

4. MA Y., CHEN W. A Comparative Analysis of Soil Water Retention Curves for Natural and Compacted Loess. Electronic Journal of Geotechnical Engineering, 22 (13), 2017.

5. LIU X., ZHANG M., ZHANG H., JIA Y., ZHU C., SHAN H. Physical and Mechanical Properties of Loess Discharged from the Yellow River into the Bohai Sea, China. Engineering Geology, 227, 4, 2017.

6. LIU Z., LIU F., MA F., WANG M., BAI X., ZHENG Y., YIN H., ZHANG G. Collapsibility, Composition, and Microstructure of Loess in China. Canadian Geotechnical Journal, 53 (4), 673, 2016.
7. XU Z., LIN Z., ZHANG M. Loess in China and Loess Landslides [J]. Chinese Journal of Rock Mechanics and Engineering, 26 (7), 1297, 2007.

8. SCHAETZL R.J., ATTIG J.W. The Loess Cover of Northeastern Wisconsin. Quaternary Research, 79 (2), 199, 2013.

9. SHRODER J.F., SCHETTLER M.J., WEIHS B.J. Loess Failure in Northeast Afghanistan. Physics and Chemistry of the Earth, Parts A/B/C, 36 (16), 1287, 2011.

10. YATES K., FENTON C., BELL D. A Review of the Geotechnical Characteristics of Loess and Loess-Derived Soils from Canterbury, South Island, New Zealand. Engineering Geology, 236, 11, 2018.

11. CHEN H., SHAO M., LI Y. Soil Desiccation in the Loess Plateau of China. Geoderma, 143 (1-2), 91, 2008.

12. ZHAO G., MU X., WEN Z., WANG F., GAO P. Soil Erosion, Conservation, and Eco-Environment Changes in the Loess Plateau of China. Land Degradation \& Development, 24 (5), 499, 2013.

13. SHI H., SHAO M. Soil and Water Loss from the Loess Plateau in China. Journal of arid environments, 45 (1), 9 , 2000.

14. CHEN L., WEI W., FU B., LÜ Y. Soil and Water Conservation on the Loess Plateau in China: Review and Perspective. Progress in Physical Geography, 31 (4), 389, 2007.

15. CUI Z., HAO J., PAN P., LI J., CHEN M. Freeze-Thaw Deformation Characteristics of Compacted Loess in Winter Irrigation Area under Insufficient Water Supply [J]. Journal of Ningxia University (Natural Science Edition), 39 (3), 234, 2018.

16. CUI Z., ZHOU W., PAN P., LI J. Thixotropic Properties of Ningxia Concentric Reshaping Loess [J]. Journal of Hydroelectric Engineering, 35 (6), 111, 2016.

17. CUI Z. Time Effect of Reshaping the Collapsibility of Loess. „Industrial Construction“ 2016 Supplement II: Industrial Construction Magazine, 2016.

18. ZHOU A., WU S., LI J., SHENG D. Including Degree of Capillary Saturation into Constitutive Modelling of Unsaturated Soils. Computers and Geotechnics, 95, 82, 2018.

19. ZHANG X., LIU S., WANG Q., WANG G., LIU Y., PENG W., XU X., LIU Y. Experimental Investigation of Water Migration Characteristics for Saline Soil. Polish Journal of Environmental Studies, 28 (3), 1495, 2019.

20. LI G., MA W., WANG F., MU Y., MAO Y., HOU X., BING H. Processes and Mechanisms of Multi-Collapse of Loess Roads in Seasonally Frozen Ground Regions: A Review. Sciences in Cold and Arid Regions, 7 (4), 456, 2018.

21. HU Z., CHENG Y. Effectiveness of Non-Suction Controlled Method of Wetting-Drying Cycles for Unsaturated Compacted Loess Material. Key Engineering Materials.; Trans Tech Publ, 748, 346, 2017.

22. CHEN S., MA W., LI G. Study on the Mesostructural Evolution Mechanism of Compacted Loess Subjected to Various Weathering Actions. Cold Regions Science and Technology, 167, 2019.

23. LI G., WANG F., MA W., FORTIER R., MU Y., MAO Y., HOU X. Variations in Strength and Deformation of Compacted Loess Exposed to Wetting-Drying and FreezeThaw Cycles. Cold Regions Science and Technology, 151, 159, 2018.

24. XU X., WANG B., FAN C., ZHANG W. Strength and Deformation Characteristics of Silty Clay under Frozen and Unfrozen States. Cold Regions Science and Technology, 2020. 
25. DONG D., GAO H., ZHAO Q., DONG Q., ZHOU J. Analysis on Moisture Migration Law in Loess Fill Subgrade. Journal of Engineering Science \& Technology Review, 12 (4), 2019.

26. ZHANG C., LI L., LOCKINGTON D. Numerical Study of Evaporation-Induced Salt Accumulation and Precipitation in Bare Saline Soils: Mechanism and Feedback. Water Resources Research, 50 (10), 8084, 2014.

27. LAI Y., PEI W., ZHANG M., ZHOU J. Study on Theory Model of Hydro-Thermal-Mechanical Interaction Process in Saturated Freezing Silty Soil. International Journal of Heat and Mass Transfer, 78, 805, 2014.

28. WU D., LAI Y., ZHANG M. Thermo-Hydro-SaltMechanical Coupled Model for Saturated Porous Media Based on Crystallization Kinetics. Cold Regions Science and Technology, 133, 94, 2017.

29. DE GUZMAN E.M.B., STAFFORD D., ALFARO M.C., DORé G., ARENSON L.U. Large-Scale Direct Shear Testing of Compacted Frozen Soil under Freezing and Thawing Conditions. Cold Regions Science and Technology, 151, 138, 2018.

30. TAVAKOLI DASTJERDI M., HABIBAGAHI G., NIKOOEE E. Effect of Confining Stress on Soil Water Retention Curve and Its Impact on the Shear Strength of Unsaturated Soils. Vadose Zone Journal, 13 (5), 2014.

31. ZHANG Q., WERNER A.D., AVIYANTO R.F., HUTSON J.L. Influence of Soil Moisture Hysteresis on the Functioning of Capillary Barriers. Hydrological Processes: An International Journal, 23 (9), 1369, 2009.

32. SCHEUERMANN A., BIEBERSTEIN A. Determination of the Soil Water Retention Curve and the Unsaturated Hydraulic Conductivity from the Particle Size Distribution. Experimental unsaturated soil mechanics.; Springer, 421, 2007.

33. WANG M., BAI X. Collapse Property and Microstructure of Loess. Advances in Unsaturated Soil, Seepage, and Environmental Geotechnics, 111, 2006.

34. LUO J., TANG L., LING X., GENG L. Experimental and Analytical Investigation on Frost Heave Characteristics of an Unsaturated Moderately Expansive Clay. Cold Regions Science and Technology, 155, 343, 2018.

35. YAN C., WAN Q., XU Y., XIE Y., YIN P. Experimental Study of Barrier Effect on Moisture Movement and Mechanical Behaviors of Loess Soil. Engineering Geology, 240, 1, 2018

36. WANG G., LI B., FU H. Experimental Study of Moisture Migration of Unsaturated Soil in Embankment. Rock and Soil Mechanics, 1, 2010.

37. WANG T., LIU J., TIAN Y. Static Properties of Cement and Lime-Modified Soil Subjected to Freeze-Thaw Cycles. Rock and Soil Mechanics, 32 (1), 193, 2011.

38. AMINI O., GHASEMI M. Laboratory Study of the Effects of Using Magnesium Slag on the Geotechnical Properties of Cement Stabilized Soil. Construction and Building Materials, 223, 409, 2019.

39. BO S., CHANGMING W., DON G., TAN G. Experimental Study on Improving Collapsible Loess with Cement. Global geology, 13 (2), 2010.

40. ZHANG S., YANG X., XIE S., YIN P. Experimental Study on Improving the Engineering Properties of Coarse Grain Sulphate Saline Soils with Inorganic Materials. Cold Regions Science and Technology, 170, 2020.

41. WANG S., LV Q., BAAJ H., LI X., ZHAO Y. Volume Change Behaviour and Microstructure of Stabilized Loess under Cyclic Freeze-Thaw Conditions. Canadian Journal of Civil Engineering, 43 (10), 865, 2016.
42. WHITE I., KNIGHT J., ZEGELIN S., TOPP G. Comments on 'Considerations on the Use of Time-Domain Reflectometry (Tdr) for Measuring Soil Water Content'by Wr Whalley. European Journal of Soil Science, 45 (4), 503, 1994.

43. HUISMAN J., WEERTS A., HEIMOVAARA T., BOUTEN W. Comparison of Travel Time Analysis and Inverse Modeling for Soil Water Content Determination with Time Domain Reflectometry. Water Resources Research, 38 (6), 13, 2002.

44. JU Z., LIU X., REN T., HU C. Measuring Soil Water Content with Time Domain Reflectometry: An Improved Calibration Considering Soil Bulk Density. Soil science, 175 (10), 469, 2010.

45. SOUZA C., OR D., MATSURA E. A Variable-Volume Tdr Probe for Measuring Water Content in Large Soil Volumes. Soil Science Society of America Journal, 68 (1), 25, 2004.

46. NADLER A., GAMLIEL A., PERETZ I. Practical Aspects of Salinity Effect on Tdr-Measured Water Content a Field Study. Soil Science Society of America Journal, 63 (5), 1070, 1999.

47. TAN X., WU J., HUANG J., WU M., ZENG W. Design of a New Tdr Probe to Measure Water Content and Electrical Conductivity in Highly Saline Soils. Journal of soils and sediments, 18 (3), 1087, 2018.

48. GIACHETTI M., ARINGHIERI R. Assessing Soil Volumetric Water Content and Salinity by Time Domain Reflectometry. International Symposium on Techniques to Control Salination for Horticultural Productivity 573, 29, 2000.

49. LIKOS W.J., LU N. Hysteresis of Capillary Stress in Unsaturated Granular Soil. Journal of Engineering mechanics, 13 (6), 646, 2004.

50. ODONG J. Evaluation of Empirical Formulae for Determination of Hydraulic Conductivity Based on GrainSize Analysis. Journal of American Science, 3 (3), 54, 2007.

51. HUSSAIN F., NABI G. Empirical Formulae Evaluation for Hydraulic Conductivity Determination Based on Grain Size Analysis. Int. J. Res. Env. Std, 3 (3), 26, 2016.

52. ZHAO M., LIU X., AN C. Analysis of Capillary Effect in Unsaturated Roadbed. Journal of Highway and Transportation Research and Development, 8, 149, 2008.

53. ZHANG X., LI M., SUN Y., ZHU Y., YANG Z., TIAN D. Study on Permeability Coefficient of Saturated Cohesive Soil Based on Fractal Theory. IOP Conference Series: Earth and Environmental Science.; IOP Publishing, 242 (6), 2019.

54. SILLERS W.S., FREDLUND D.G., ZAKERZADEH N. Mathematical Attributes of Some Soil-Water Characteristic Curve Models. Unsaturated soil concepts and their application in geotechnical practice.; Springer, 243, 2001.

55. MAO X., HOU Z., KONG L. Experimental Study on Moisture Migration of Wind-Blown Sand[J]. Journal of Hydraulic Engineering, 41 (2), 142, 2010.

56. ROMERO E., VAUNAT J. Retention Curves of Deformable Clays. Experimental evidence and theoretical approaches in unsaturated soils.; CRC Press, 99, 2000.

57. KARUBE D., KAWAI K. The Role of Pore Water in the Mechanical Behavior of Unsaturated Soils. Geotechnical \& Geological Engineering, 19 (3-4), 211, 2001.

58. ZHOU B., KONG L. Effect of Volume Changes on SoilWater Characteristics of Unsaturated Expansive Soil[J]. Journal of Hydraulic Engineering, 42 (10), 1152, 2011. 